\title{
Effect of Polychlorinated Biphenyls on Lipids and Ascorbic Acid Metabolism in Streptozotocin- Induced Diabetic Rats
}

\author{
Kyoko KAWAI-KobAYASHI and Akira YoshidA ${ }^{1}$ \\ Department of Agricultural Chemistry, Nagoya University, \\ Chikusa-ku, Nagoya 464, Japan \\ (Received December 16, 1987)
}

\begin{abstract}
Summary Metabolic changes in lipids, ascorbic acid, and hepatic microsomal cytochrome P-450 by feeding polychlorinated biphenyls (PCB) were investigated in streptozotocin-induced diabetic rats. Streptozotocin (STZ, $60 \mathrm{mg} / \mathrm{kg}$ body weight) was injected in Wistar male rats intraperitoneally. Diabetic and non-diabetic rats were fed ad libitum a $20 \%$ casein-based control diet or a PCB-containing diet $(200 \mathrm{mg} / \mathrm{kg}$ diet $)$ for 9 days. Body weight decreased significantly in STZ-induced diabetic rats with or without PCB (groups PD and D, respectively). In rats of group $\mathrm{D}$, urinary ascorbic acid excretion was 15 times higher than that in non-diabetic rats fed a control diet (group C). Dietary PCB caused 30-fold higher urinary ascorbic acid excretion in non-diabetic rats (group P) than that in group C. In group PD, urinary ascorbic acid was nearly 60 times higher than that in group C. Ascorbic acid in liver and kidney was significantly lower in group D than in group $\mathrm{C}$, and it was significantly lower in group PD than in group P. Liver microsomal cytochrome P-450 and $b_{5}$ were both increased by dietary PCB in group P. Addition increase in these enzymes was observed in diabetic rats by PCB. Serum total cholesterol was 1.8 times higher in group $\mathbf{P}$ than in group $\mathrm{C}$. Further increase in serum total cholesterol was observed in group PD. These data suggested that metabolic changes in lipids and ascorbic acid induced by the dietary xenobiotic were magnified in STZ-induced diabetic rats.
\end{abstract}

Key Words PCB, streptozotocin-diabetes, ascorbic acid, serum cholesterol

Administration of polychlorinated biphenyls (PCB) to rats causes increases in serum cholesterol concentration, tissue and urinary ascorbic acid levels, and activities of liver microsomal drug-metabolizing enzymes (1-3). Similar observations have been reported with other xenobiotics, including 1,1,1-trichloro-2,2-

\footnotetext{
1 小林(河合) 京子，吉田 昭
} 
bis( $p$-chlorophenyl)ethan (DDT), 2,6-di-tert-butyl-p-cresol (BHT), pentobarbital and caffeines $(2,4-8)$. We previously reported that dietary PCB also caused increased thiobarbituric acid-reactive substances (TBA-RS) which are known as an indicator of lipid peroxidation $(9,10)$. Liver lipid accumulation by some xenobiotics is also reported $(10,11)$. On the other hand, changed lipid metabolism including hypercholesterolemia, hypertriglyceridemia, and liver lipid peroxidation are also important in aging, along with some diseases such as atherosclerosis, coronary heart diseases, obesity, diabetes, and so on (12). There is a possibility that dietary xenobiotics may cause more severe metabolic changes in disease or aged condition(13). Chawalit et al. suggested the changed characteristics in hepatic drugmetabolizing enzymes of diabetic rats (14). Although there are many studies on metabolic changes caused by xenobiotics in healthy animals, the effect of xenobiotics on the metabolic changes in animals with disease was unknown. In this study, we compared the metabolic changes induced by dietary PCB in non-diabetic rats and in streptozotocin-induced diabetic rats.

\section{MATERIALS AND METHODS}

Animals and diets. Rats were acquired from Agricultural Cooperative Association for Laboratory Animals (Hamamatsu, Japan). Male rats of the Wistar strain weighing 180-185 g were used in this experiment. All the diets and tap water were supplied ad libitum. Room temperature was kept at $22 \pm 2^{\circ} \mathrm{C}$, and a $12 \mathrm{~h}$ lightdark cycle was maintained $(0800-2000 \mathrm{~h}$ light). Animals were caged individually, and checked and weighed daily.

Experiment. Before the experiment, rats were fed a stock diet (CE-2, Nippon Clear Co., Ltd., Tokyo) for several days to allow them to adapt to the new environment. Rats were then fed a control diet (Table 1) for 5 days. Rats were subsequently divided into 4 groups of 6 animals each. Two groups of rats were injected intraperitoneally with streptozotocin (STZ, Sigma Chem. Co., St Louis, Mo.) in doses $60 \mathrm{mg} / \mathrm{kg}$ body weight. The STZ was freshly dissolved in saline and was injected within $5 \mathrm{~min}$ of its preparation. The volume of administered solution did not exceed $0.5 \mathrm{ml}$ for each rat. Two other groups of rats were injected with $0.5 \mathrm{ml}$ of saline. Urine was checked by Tess tape (Ely Lilly Co., Ltd., Ind.) for glucose, after $12 \mathrm{~h}$ of STZ injection. One group each from the two non-diabetic and the two diabetic groups was fed a control diet (groups C and D, respectively) or a $200 \mathrm{mg} / \mathrm{kg}$ diet of polychlorinated biphenyls (PCB (17), Mitsubishi Monsanto Co., Ltd., Tokyo)-containing diet (groups $\mathrm{P}$ and PD, respectively) for 9 days. After 7 days of feeding the test diets, urine was collected for $24 \mathrm{~h}$ into $15 \mathrm{ml}$ of $5 \%$ metaphosphoric acid, filtered, and used for determination of ascorbic acid excretion by the dinitrophenyl hydrazine method (18). On the last day of the experimental period, diet was removed from the individual cages at $0900 \mathrm{~h}$. The rats were anesthetized with ether and killed at $1330 \mathrm{~h}$ within a 40 -min period. Blood was collected by heart puncture. Fresh whole blood was taken by a heparinized capillary 
Table 1. Composition of the control diet.

\begin{tabular}{lc}
\hline Constituents & Amount \% \\
\hline Casein & 20 \\
Salt mixture & 5 \\
Vitamin mixture $^{\mathrm{b}}$ & 1 \\
Corn oil $^{\mathrm{C}}$ & 5 \\
Cellulose powder & 4 \\
Starch : sucrose $(2: 1)$ & 64.9 \\
Choline chloride & 0.1 \\
Se (as $\left.\mathrm{Na}_{2} \mathrm{SeO}_{3}\right)(\mathrm{mg} / \mathrm{kg})$ & 0.1 \\
\hline
\end{tabular}

${ }^{\mathrm{a}}$ The salt mixture includes the following salts (g/100 g of salt mixture): $\mathrm{CaHPO}_{4} \cdot 2 \mathrm{H}_{2} \mathrm{O}$, $0.43 ; \mathrm{KH}_{2} \mathrm{PO}_{4}, 34.31 ; \mathrm{NaCl}, 25.06 ; \mathrm{Fe}$-citrate, $0.623 ; \mathrm{MgSO}_{4} \cdot 7 \mathrm{H}_{2} \mathrm{O}, 9.98 ; \mathrm{ZnCl}_{2}$, $0.02 ; \mathrm{MnSO}_{4} \cdot 4 \mathrm{H}_{2} \mathrm{O}, 0.121 ; \mathrm{CuSO}_{4} \cdot 5 \mathrm{H}_{2} \mathrm{O}, 0.156 ; \mathrm{KI}, 0.005 ; \mathrm{CaCO}_{3}, \quad 29.29$; $\left(\mathrm{NH}_{4}\right)_{6} \mathrm{Mo}_{7} \mathrm{O}_{24} \cdot 4 \mathrm{H}_{2} \mathrm{O}, 0.0025(15) .{ }^{\mathrm{b}} \mathrm{A} 1 \%$ amount of the vitamin mixture in the diet provided the following vitamins in $\mathrm{mg} / \mathrm{kg}$ diet; thiamin- $\mathrm{HCl}$, 6; riboflavin, 6; pyridoxine$\mathrm{HCl}$, 7; nicotinic acid, 30; Ca-pantothenate, 16; folic acid, 2; biotin, 0.2; menadione, 0.05 ; retinyl palmitate, 2.67 (4,000 IU); ergocalciferol, 0.025 (1,000 IU); $d l-\alpha$-tocopheryl acetate, 100 (100 IU) (16).

(Drummond Sci. Co., Broomall, Pa.) and blood glucose was analyzed by the glucose oxidase method (19). The rest of the blood was let stand for clotting and centrifuged $(1,200 \times g, 10 \mathrm{~min})$ to obtain serum. Serum total cholesterol was determined by the method of Pearson et al. (20). Serum triglyceride was measured with a commercially available kit (Boehringer Mannheim Yamanouchi Co., Ltd., Tokyo)(21). Liver, spleen, kidney, adrenal, and epididymal adipose tissue were immediately removed, washed in cold saline, wiped off, and weighed. Fresh liver was used for the thiobarbituric acid-reactive substances (TBA-RS) test as we reported previously $(10,22)$. Part of the liver was homogenized with ice-cold $1.15 \%$ $\mathrm{KCl}$ in $0.01 \mathrm{M}$ phosphate buffer ( $\mathrm{pH} 7.4,20 \%$ wt./vol.) with a Potter-Elvehjem homogenizer. The homogenates were centrifuged for $10 \mathrm{~min}$ at $10,000 \times g\left(\right.$ at $\left.4^{\circ} \mathrm{C}\right)$ and the postmitochondrial supernatant was centrifuged for $60 \mathrm{~min}$ at $105,000 \times g$ $\left(\right.$ at $2{ }^{\circ} \mathrm{C}$ ). The microsomal pellets were suspended in $0.05 \mathrm{M}$ phosphate buffer ( $\mathrm{pH}$ 7.6) containing $10 \mathrm{~mm}$ EDTA, and this suspension was used for the determination of the amount of cytochrome P-450 and $b_{5}(23)$. Liver microsomal protein was analyzed subsequently (24). The rest of the tissues were stored in a freezer maintained at $-20^{\circ} \mathrm{C}$ until tissue ascorbic acid and liver lipids were analyzed $(18,25)$.

Statistical analysis. Statistical significance of differences between values was analyzed by analysis of variance (ANOVA) and Student's $t$-test (26).

\section{RESULTS}

Diabetes was induced in rats by streptozotocin injection, and the existence of Vol. 34, No. 3, 1988 
severe insulin insufficiency was apparent by the occurrence of marked weight loss (Table 2), and enhanced blood glucose concentration (Table 3). All the diabetic rats fed both control or PCB diet showed polyuria and polydipsia. The average urinary volume $(\mathrm{ml} /$ day, mean $=\mathrm{SEM})$ of rats was $18 \pm 5,176 \pm 34,16 \pm 4,161 \pm 39$ for groups $\mathrm{C}, \mathrm{D}, \mathrm{P}$, and $\mathrm{PD}$, respectively.

Dietary addition of PCB had no effect on the growth of non-diabetic rats (group P), nor on the body weight loss of diabetic rats (group PD) (Table 2). Liver weight increased significantly in groups $P$ and $P D$ (Table 2). In rats of group $P$, spleen weight was significantly lower than that in group $C$. The spleen weight did not change between group D and PD. Kidney weight increased in rats of groups D and PD. Adrenal weight was significantly higher in groups D, P, and PD than in group C. Epididymal adipose tissue in rats of group $P$ showed significant increase in weight. In rats of groups $\mathrm{D}$ and $\mathrm{PD}$, epididymal adipose tissue weight decreased significantly (Table 2).

Dietary PCB did not affect the blood glucose in non-diabetic rats. But the blood glucose in group PD decreased more slightly than that in group D. Serum total cholesterol increased significantly in groups $\mathrm{P}$ and $\mathrm{PD}$ compared with that in groups $\mathrm{C}$ and $\mathrm{D}$, by $70-80 \%$. The rats of group PD showed significantly higher serum cholesterol than that in group P. Triglyceride in serum was significantly higher in groups D and $P$ than that in group C. Liver TBA-RS was significantly higher in groups D, PD, and $\mathrm{P}$ than that in group $\mathrm{C}$. Liver microsomal protein in groups $\mathrm{D}$ and $\mathrm{PD}$ was significantly lower than that in groups $\mathrm{C}$ and $\mathrm{P}$. Liver microsomal cytochrome P-450 was increased significantly by a PCB diet in groups $\mathrm{P}$ and PD compared to that in groups $C$ and D, respectively. Cytochrome P-450 in group PD was higher than that in group $\mathrm{P}$. Liver microsomal cytochrome $b_{5}$ was significantly higher in groups D, PD, and $\mathrm{P}$ than that in group C. Liver total lipids increased significantly in groups $\mathbf{P}$ and $\mathrm{PD}$ than in groups $\mathrm{C}$ and $\mathrm{D}$. Urinary ascorbic acid excretion in group $\mathrm{D}$ was significantly higher in comparison with that in group C. Dietary addition of PCB significantly increased urinary ascorbic acid excretion in groups P and PD (Table 4). Liver ascorbic acid concentration was 3fold higher in rats of groups $\mathrm{P}$ and $\mathrm{PD}$ than that in groups $\mathrm{C}$ and $\mathrm{D}$, respectively. In rats of groups $\mathrm{D}$ and $\mathrm{PD}$, liver ascorbic acid was lower by $50 \%$ than that in groups $\mathrm{C}$ and $\mathrm{P}$, respectively. Spleen ascorbic acid also increased in groups $\mathrm{P}$ and $\mathrm{PD}$ compared to that in groups $\mathrm{C}$ and $\mathrm{D}$, respectively. Kidney ascorbic acid decreased by $50 \%$ in group D compared to that in group C. Dietary PCB increased kidney ascorbic acid in groups $\mathrm{P}$ and $\mathrm{PD}$ compared to that in groups $\mathrm{C}$ and $\mathrm{D}$, respectively. Adrenal ascorbic acid was higher in groups $\mathrm{P}$ and $\mathrm{PD}$ than in groups $\mathrm{C}$ and $\mathrm{D}$.

\section{DISCUSSION}

Administration of PCB to rats causes an increase in activities of drugmetabolizing enzymes and an increase in serum cholesterol concentration as well as liver and urinary ascorbic acid (2). These metabolic changes may be manifestations 
DIABETIC RATS FED PCB

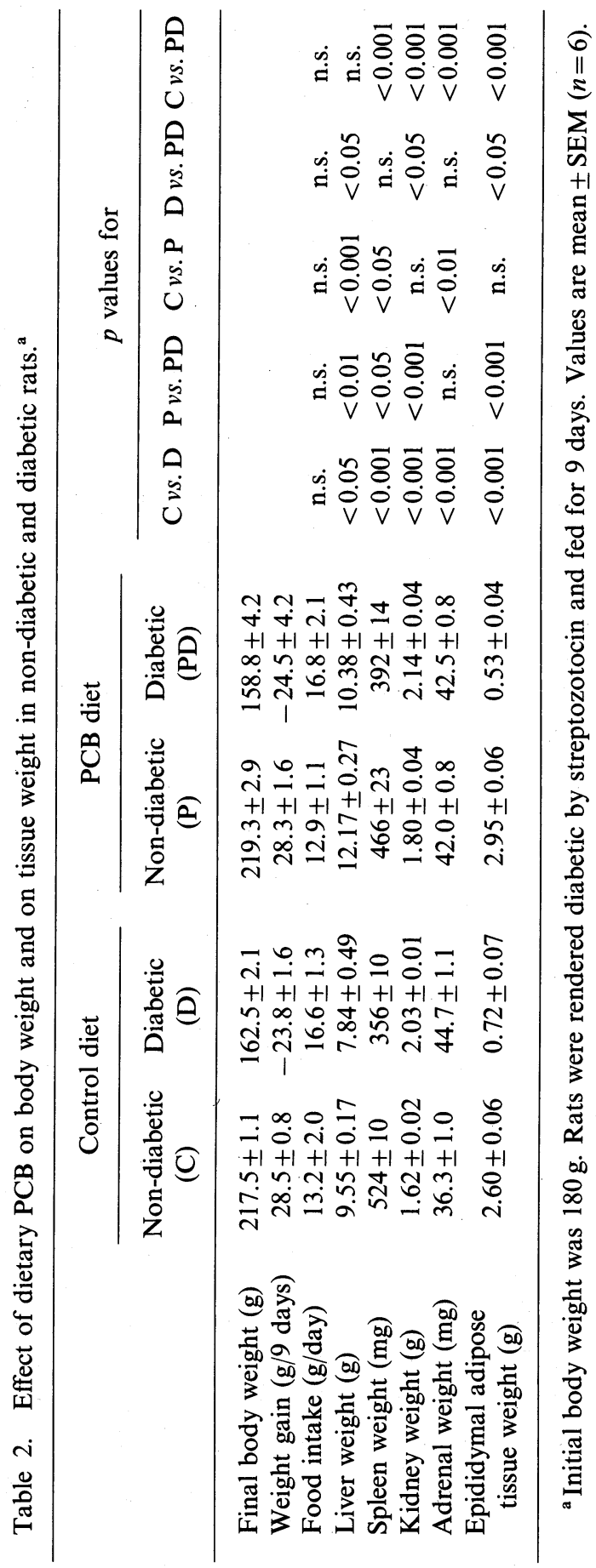




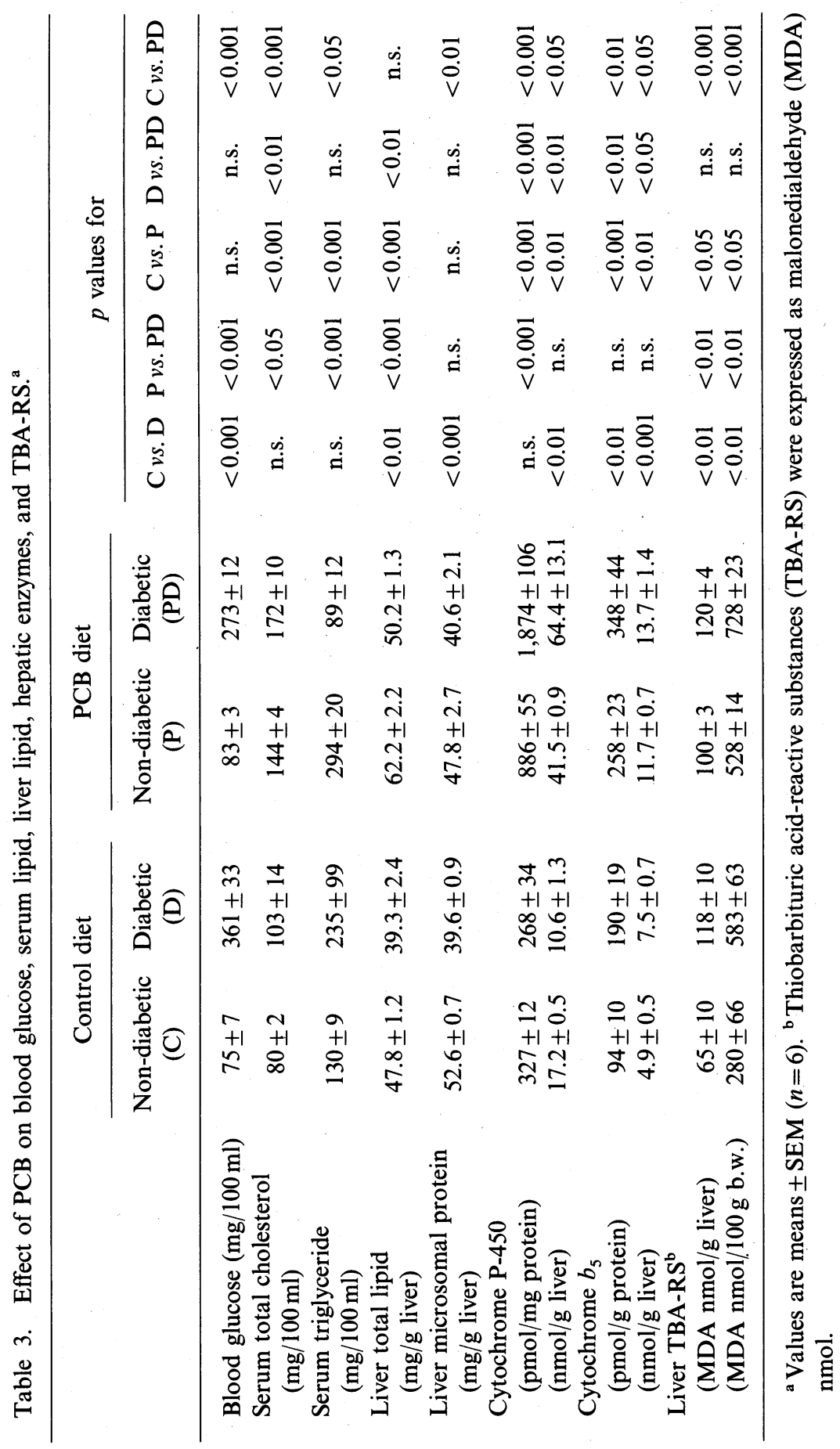




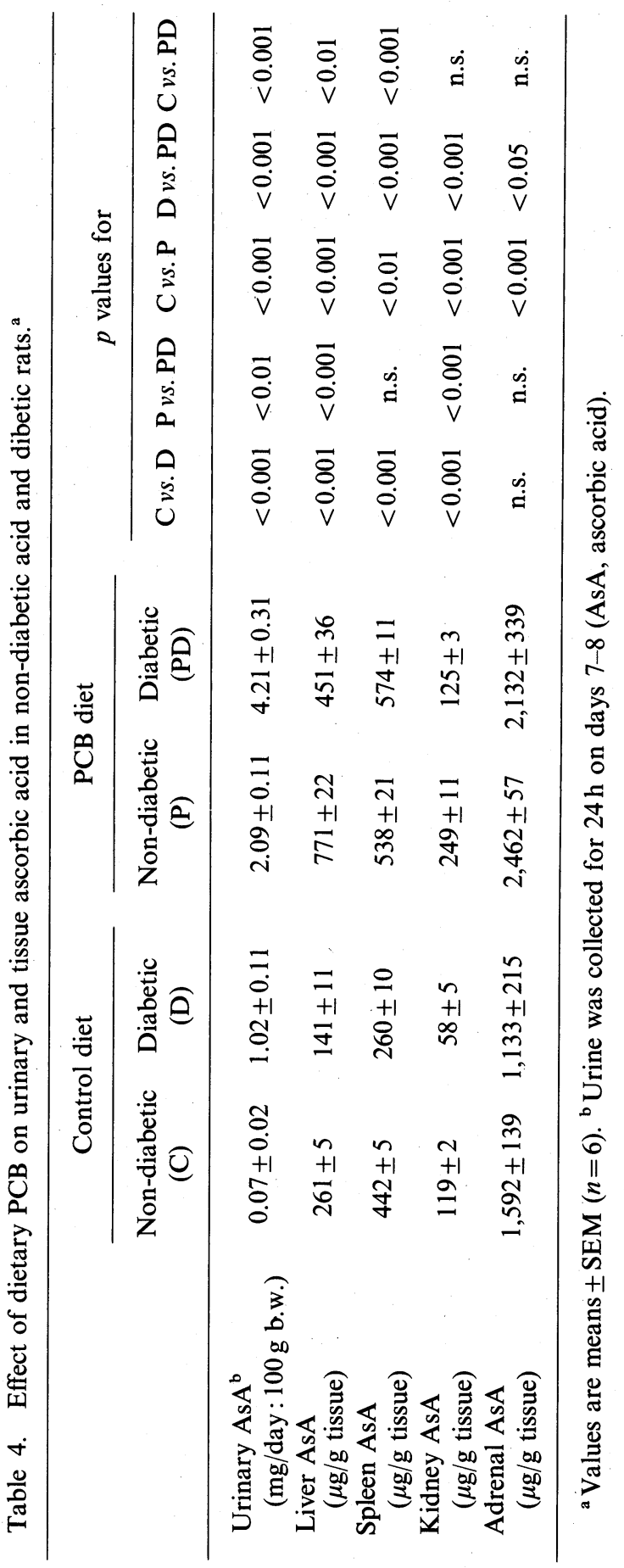

Vol. 34, No. 3; 1988 
not only of toxicity of PCB but also of protective responses of rats fed PCB, since drug-metabolizing enzymes are responsible for the oxidative metabolism of xenobiotics to polar metabolites. The elevated concentration of tissue ascorbic acid may be beneficial for the animals treated with PCB, since high dietary ascorbic acid lowered PCB toxicity in guinea pigs, which are unable to synthesize the vi$\operatorname{tamin}(9,10,27)$. And the maximum induction of drug-metabolizing enzymes by dietary PCB was observed in osteogenic disorder rats (which cannot synthesize ascorbic acid) fed higher ascorbic acid than the level sufficient for maximum growth and the prevention of scurvy (28). Elevated urinary ascorbic acid excretion observed in STZ-induced diabetic rats may be at least partly explained by polyuria..Ascorbic acid concentration in urine is not so high in diabetic rats, but the increased volume of urine exaggerates the total ascorbic acid excretion per day. Decreased liver and kidney ascorbic acid may also be due to the polyuria and increased kidney weight in diabetic rats. The capacity of reabsorption for ascorbic acid in kidney may be lowered by severe diabetes as shown in body weight loss and polyuria. The low capacity of ascorbic acid reabsorption in kidney may explain increased ascorbic acid loss in urine in STZ-induced diabetic rats, especially in rats exposed to PCB. There is substantial evidence that the increase in tissue ascorbic acid results from an acceleration in the rate of synthesis of ascorbic acid in the rats fed diets containing xenobiotics (29). Lower ascorbic acid concentration in tissues is thought to be due to the larger loss of ascorbic acid in urine in diabetic rats. This may suggest the increased ascorbic acid requirement in diabetic subjects which cannot synthesize the vitamin, such as human and guinea pigs when they are exposed to xenobiotics.

It is reported that the high serum level of cholesterol in rats fed a PCBcontaining diet is mainly due to the elevated 3-hydroxy-3-methylglutaryl coenzyme A (HMG CoA) reductase (EC 1.1.1.34; rate limiting enzyme of cholesterol biosynthesis) activity in liver microsomes (30). On the other hand, Saudek and Young suggested that the elevated serum cholesterol in diabetic rats is due to the increased HMG CoA reductase activity in intestine which is attributed to hyperphagia (31). Chait et al. reported that insulin increased the number of low-density lipoprotein (LDL)-receptors in cultured human skin fibroblast (32). Thus, serum cholesterol catabolism is possibly lowered in insulin deficiency in insulin-dependent diabetic (IDD) rats. The significantly higher cholesterol level in rats of group PD than in the other groups may be due to not only the increased cholesterol synthesis in both liver and intestine, but also the low catabolism of cholesterol. Nikkilä et al. reported the impaired triglyceride catabolism in IDD rats by lowered peripheral lipoprotein lipase (33). Triglyceride in very low density lipoprotein and chylomicron is incorporated into peripheral tissues via lipoprotein lipase. Increased serum triglyceride in rats of group D is explained by low lipoprotein lipase activity. But in rats of group PD, there is no interpretation of lower serum triglyceride. The low weight of epididymal adipose tissue suggested the increased lipid catabolism in peripheral tissue in rats of groups D and PD (Table 2). In IDD rats, lipogenesis may be depressed mainly in the liver (34). Liver lipid may be used as an energy source in 
diabetic rats so that liver total lipids is decreased. Decreased liver microsomal protein suggested that glycogenic amino acid was used as an energy source, as well as liver lipid (37). Liver microsomal cytochrome P-450 and $b_{5}$ were elevated by dietary PCB as described previously (1-3). Elevated drug-metabolizing enzymes may contribute to the increased TBA-RS via drug metabolism (10). Enhanced serum TBA-RS was reported in diabetic subjects (35). Dietary PCB caused elevated liver TBA-RS as we reported previously $(9,10)$. The liver TBA-RS was higher in group D than in group C. And group PD showed higher TBA-RS than in group D. Wendel and Feuerstein suggested that the radicals released from the drug-metabolizing enzyme system during the metabolism of xenobiotics is related to enhanced liver lipid peroxidation (36).

In this study, general metabolic changes by dietary PCB in STZ-induced diabetic rats were compared to those in non-diabetic rats. Some changes especially in lipids and ascorbic acid metabolism were exaggerated in diabetic rats by exposure to dietary PCB. The STZ-induced diabetic rat is a model of IDD. The effect of xenobiotics on metabolic changes in non-insulin-dependent diabetes is also quite important, and should be studied. The possible changes in nutritional requirement due to xenobiotics intake should be considered in healthy subjects, in subjects with disease, and in aged subjects, since all may be exposured to a variety of food chemicals, possibly through the food chain or medication.

This work was partly supported by grants from the Japan Society for the Promotion of Science for Japanese Junior Scientists and from the Elizabeth Arnold Fuji Foundation.

\section{REFERENCES}

1) Ishikawa, T. T., Mcneely, S., Steiner, P. M., Glueck, C. J., Mellies, M., Gartside, P. S., and McMillin, C. (1978): Effects of chlorinated hydrocarbons on plasma-lipoprotein cholesterol in rats. Metabolism, 27, 89-96.

2) Kato, N., and Yoshida, A. (1979): Effects of some fat-soluble chemicals on plasma cholesterol and urinary ascorbic acid in rats. Agric. Biol. Chem., 43, 191-192.

3) Carter, J. W. (1984): Hypercholesterolemia induced by dietary PCBs (Aroclor 1254) in fisher rats. Bull. Environ. Contam. Toxicol., 33, 78-83.

4) Kato, N., Kato, M., Kimura, T., and Yoshida, A. (1978): Effect of dietary addition of PCB, DDT or BHT and dietary protein on vitamin A and cholesterol metabolism. Nutr. Rep. Int., 18, 437-445.

5) Kato, N., and Yoshida, A. (1981): Effects of dietary xenobiotics on serum total cholesterol and high density lipoprotein cholesterol in rats. Nutr. Rep. Int., 23, 825-831.

6) Kato, N., Tani, T., and Yoshida, A. (1980): Effect of dietary level of protein on liver microsomal drug-metabolizing enzymes, urinary ascorbic acid and lipid metabolism in rats fed PCB-containing diets. J. Nutr., 110, 1686-1694.

7) Conney, A. H., and Burns, J. J. (1959): Stimulatory effect of foreign compounds on ascorbic acid biosynthesis and on drug-metabolizing enzymes. Nature, 184, 363-365.

8) Magdolna, K., Robert, T., Magdolna, B., Erns, D., Magda, T. K., and Eva, W. J. (1969): Effect of caffeine and barbiturates on the metabolism of rats. Egeszsegutudomany, 13, 293-300. 
9) Kato, N., Kawai, K., and Yoshida, A. (1981): Effect of dietary level of ascorbic acid on the growth, hepatic lipid peroxidation, and serum lipids in guinea pigs fed polychlorinated biphenyls. J. Nutr., 111, 1727-1733.

10) Kawai-Kobayashi, K., and Yoshida, A. (1986): Effect of dietary ascorbic acid and vitamin $\mathrm{E}$ on metabolic changes in rats and guinea pigs exposed to PCB. J. Nutr., 116, 98-106.

11) DiLuzio, N. R. (1973): Antioxidants, lipid peroxidation and chemical-induced liver injury. Fed. Proc., 32, 1875-1881.

12) Rifkind, B. M. (1986): Diet, plasma cholesterol and coronary heart disease. J. Nutr., 116, 1578-1580.

13) Schmucker, D. L. (1985): Aging and drug disposition: An update. Pharmacol. Rev., 37, 133-148.

14) Chawalit, K., Sretarugsa, P., and Thithapanda, A. (1982): Comparative effects of diabetogenic agents on hepatic drug metabolism. Drug. Metabol. Dispos., 10, 81-86.

15) Harper, A. E. (1959): Amino acid balance and imbalance. J. Nutr., 68, 405-418.

16) Report of the American Institute of Nutrition Ad Hoc Committee on standards for nutritional studies (1977): J. Nutr., 107, 1340-1348.

17) WHO (1976): Polychlorinated biphenyls, in Environmental Health Criteria 2, World Health Organization, Geneva, p. 18.

18) Roe, J. H., Mills, M. B., Oesterling, M. J., and Darson, C. M. (1948): The determination of diketo-1-gulonic acid, dehydro-1-ascorbic acid, in the same tissue extract by the 2,4-dinitrophenyl hydrazine method. J. Biol. Chem., 174, 201-208.

19) Salomon, L. L., and Johnson, J. E. (1959): Enzymatic micro-determination of glucose in blood and urine. Anal. Chem., 31, 453-456.

20) Pearson, S., Stern, S., and McGavack, T. H. (1953): A rapid, accurate method for the determination of total cholesterol in serum. Anal. Chem., 25, 813-814.

21) Fletcher, M. J. (1968): A colorimetric method of estimating serum triglycerides. Clin. Chim. Acta, 22, 393-397.

22) Masugi, F., and Nakamura, T. (1977): Measurement of thiobarbituric acid value in liver homogenate solubilized with sodium dodecyl sulphate and variation of the values affected by vitamin E and drugs. Jpn. J. Vitaminol., 5, 21-29.

23) Omura, T., and Sato, R. (1964): The carbon monooxide-binding pigment of liver microsomes. I. Evidence for its hemoprotein nature. J. Biol. Chem., 239, 2370-2378.

24) Lowry, O. H., Rosebrough, N. J., Farr, A. L., and Randal, R. J. (1951): Protein measurement with the Folin phenol reagent. J. Biol. Chem., 193, 265-275.

25) Folch, J., Lees, M., and Sloane-Stanley, G. H. (1957): A simple method for the isolation and purification of total lipids from animal tissues. J. Biol. Chem., 226, 497-509.

26) Snedecor, G. W., and Cochran, W. G. (1967): Statistical Methods, 6th Ed., The Iowa State Univ. Press, Ames, Ia. (Japanese translated edition, Iwanami Publ. Inc., Tokyo), pp. 87-114.

27) Kato, N., Okada, T. Takenaka, Y., and Yoshida, A. (1977): Ameliorative effect of dietary ascorbic acid on PCB toxicity in guinea pigs. Nutr. Rep. Int., 15, 125-130.

28) Horio, F., Ozaki, K., Kohmura, M., Yoshida, A., Makino, S., and Hayashi, Y. (1986): Ascorbic acid requirement for the induction of microsomal drug-metabolizing enzymes in a rat mutant unable to synthesize ascorbic acid. J. Nutr., 116, 2278-2289.

29) Horio, F., and Yoshida, A. (1982): Effects of some xenobiotics on ascorbic acid metabolism in rats. J. Nutr., 112, 416-425.

30) Kato, N., and Yoshida, A. (1980): Effect of dietary PCB on hepatic cholesterogenesis in rats. Nutr. Rep. Int., 21, 107-112. 
31) Saudek, C. D., and Young, N. L. (1981): Metabolism in diabetes mellitus. The role of diet. Diabetes, 30, Suppl., 76-81.

32) Chait, A., Bierman, E. L., and Albers, J. J. (1979): Low-density lipoprotein receptor activity in cultured human skin fibroblasts. Mechanism of insulin-induced stimulation. J. Clin. Invest., 64, 1309-1319.

33) Nikkilä, E. A., Huttunen, J. K., and Ehnholm, C. (1979): Postheparin plasma lipoprotein lipase and hepatic lipase in diabetes mellitus. Diabetes, 26, 11-21.

34) Mayes, P. A. (1983): Regulation of carbohydrate and lipid metabolism, in Harper's Review of Biochemistry (19th Ed.), ed. by Martin, D. W. et al., Lange Maruzen, Tokyo, pp. 248-264.

35) Sato, Y., Hotta, N., Sakamoto, N., Matsuoka, S., Ohishi, N., and Yagi, K. (1979): Lipid peroxide level in plasma of diabetic patients. Biochem. Med., 21, 104-107.

36) Wendel, A., and Feuerstein, S. (1981): Drug-induced lipid peroxidation in mice I. Biochem. Pharmacol., 30, 2521-2526.

37) Grodsky, G. M. (1983): Chemistry and functions of the hormones: 3 Pancreas and gastrointestinal tract, in Harper's Review of Biochemistry (19th Ed.), ed. by Martin, D. W. et al., Lange Maruzen, Tokyo, pp. 511-522. 